\title{
Comparison of Interpretation between Pyrosequencing and Xpert MTB/RIF Assay in Multidrug-Resistant Tuberculosis
}

\author{
Linda Choerunnisa, ${ }^{1}$ Coriejati Rita, ${ }^{1}$ Anna Tjandrawati, ${ }^{1}$ Lidya Chaidir, ${ }^{2}$ Ida Parwati ${ }^{1}$ \\ ${ }^{1}$ Department of Clinical Pathology Faculty of Medicine Universitas Padjadjaran/Dr. Hasan Sadikin \\ General Hospital Bandung, Indonesia, ${ }^{2}$ Department of Biomedical Sciences Faculty of Medicine \\ Universitas Padjadjaran, Indonesia
}

\begin{abstract}
Indonesia is one of the countries with the highest multidrug-resistant tuberculosis cases in the world. Rapid molecular test using the Xpert MTB/RIF assay is one of the detection methods for MDR-TB. Early detection of MDRTB is crucial for early initiation of treatment. However, Xpert MTB/RIF assay only detects the rpoB gene mutations associated with Rifampicin resistance. Recently, WHO recommends the use of Pyrosequencing, a DNA sequencing method that can detect not only the $r p o B$ gene but also $k a t G$ and/or inhA gene mutations associated with Isoniazid resistance. The aims of this study were to compare the interpretation between the two methods and to determine the differences in codon mutation position detection of the $r p o B$ gene and mutation detection of the katG and/or inhA gene. This was a cross-sectional comparative observational study on patients $\geq 18$ years old interpreted as RR-TB patients based on Xpert MTB/RIF assay results who had not received MDR-TB drugs at Dr. Hasan Sadikin General Hospital Bandung, Indonesia. Results showed there were 40 Rifampicin-resistant TB subjects interpreted by Xpert MTB/RIF assay while Pyrosequencing interpreted 30 MDR-TB, 9 RR-TB and one Isoniazid-resistant TB subjects in January-February 2020. The detection of $r p o B$ gene codon mutation position between Xpert MTB/RIF assay and Pyrosequencing methods was not significantly different $(\mathrm{p}=0.389)$. Pyrosequencing had detected 27 katG gene mutations, 3 inhA gene mutations, one katG and inhA gene mutation. To conclude, Pyrosequencing can be used for accurate detection of Rifampicin and Isoniazid resistance in MDR-TB.
\end{abstract}

Keywords: Multidrug-resistant tuberculosis, pyrosequencing, Xpert MTB/RIF assay

\section{Perbandingan Hasil Interpretasi antara Pyrosequencing dengan Xpert MTB/ RIF Assay pada Multidrug-Resistant Tuberculosis}

\begin{abstract}
Abstrak
Indonesia merupakan salah satu negara dengan kasus multidrug-resistant tuberculosis terbanyak. Penegakan diagnosis MDR-TB saat ini menggunakan tes cepat molekular Xpert MTB/RIF assay sehingga pasien segera mendapatkan pengobatan. Namun, Xpert MTB/RIF assay hanya mendeteksi mutasi gen rpoB penyandi resistansi Rifampisin. World Health Organization merekomendasikan Pyrosequencing, metode sequencing nukleotida yang dapat mendeteksi mutasi gen $r p o B$, gen katG dan/atau inhA penyandi resistansi Isoniazid. Tujuan penelitian ini adalah menentukan apakah kedua alat ini memberikan hasil interpretasi yang sama, apakah ada perbedaan deteksi posisi mutasi kodon gen rрoB dan apakah ditemukan mutasi gen katG dan/atau inhA. Penelitian ini merupakan studi observasional komparatif dengan rancangan cross-sectional. Subjek penelitian adalah pasien usia $\geq 18$ tahun yang diinterpretasi RR-TB berdasarkan Xpert MTB/RIF assay di RSUP Dr. Hasan Sadikin Bandung dan belum mendapat pengobatan. Xpert MTB/RIF assay menginterpretasi 40 subjek Rifampicin-resistant TB sedangkan Pyrosequencing menginterpretasi 30 subjek MDR-TB, 9 subjek RR-TB, dan satu subjek Isoniazidresistant TB pada bulan Januari-Februari 2020. Deteksi posisi mutasi kodon gen rpoB antara Xpert MTB/RIF assay dan Pyrosequencing tidak berbeda bermakna ( $\mathrm{p}=0,389)$. Pyrosequencing mendeteksi 27 mutasi gen katG, 3 mutasi gen inhA, satu mutasi gen katG dan inhA. Kesimpulan, Pyrosequencing dapat digunakan untuk deteksi resistansi Rifampisin dan Isoniazid pada MDR-TB secara lebih akurat.
\end{abstract}

Kata kunci: Multidrug-resistant tuberculosis, pyrosequencing, Xpert MTB/RIF assay

Corresponding Author: Ida Parwati, Department of Clinical Pathology Faculty of Medicine Universitas Padjadjaran/Dr. Hasan Sadikin General Hospital Bandung, Jalan Pasteur No. 38 Bandung, West Java, Indonesia, Email: idaparwati2008@gmail.com/ida. parwati@unpad.ac.id 


\section{Introduction}

Indonesia has the third-highest number of tuberculosis (TB) cases worldwide and is one of the countries with the highest multidrugresistant tuberculosis (MDR-TB) cases. ${ }^{1}$ Multidrug-resistant tuberculosis is a form of TB infection caused by Mycobacterium tuberculosis (MTB) resistant to at least two of the most powerful first-line anti-TB drug treatments: Rifampicin and Isoniazid. ${ }^{1,2}$ Xpert MTB/RIF assay is recommended by the World Health Organization (WHO) since 2010 as an initial test to diagnose MDR-TB. ${ }^{3,4}$ Xpert MTB/RIF assay is a semi-quantitative nested real-time polymerase chain reaction (PCR) test that can detect deoxyribonucleic acid (DNA) of MTB rapidly. This test is also easy to perform and can detect $r p o B$ gene mutations that are associated with Rifampicin resistance using 5 probes $(A, B, C, D$, and E). ${ }^{5,6}$

Rifampicin resistance is determined by detecting maximal $\Delta$ threshold cycle $\left(\mathrm{C}_{\mathrm{T}}\right)>4$ cycles or 1-3 probes that are not complementary to 81 base pairs (bp) rров core region. ${ }^{6}$ However, the Xpert MTB/RIF assay only detects the $r p o B$ gene mutations as Rifampicin resistance is a surrogate marker of MDR-TB. ${ }^{2,5,7}$ Rifampicin-resistant TB (RR-TB) interpreted by the Xpert MTB/RIF assay diagnosed as MDR-TB was less accurate because the Xpert MTB/RIF assay cannot detect katG, inhA, and/or $a h p C$ gene mutations that are associated with Isoniazid resistance. ${ }^{8,9}$

Pyrosequencing is a DNA analysis based on nucleotide sequencing by inorganic pyrophosphate(PPi)synthesistoknownucleotide mutations directly and specifically. ${ }^{10,11}$ Recently, WHO recommends MDR-TB early detection using Pyrosequencing. ${ }^{12}$ Pyrosequencing using Pyromark Q48 Reagents Kit can detect the 81bp $r p o B$ gene as Rifampicin resistance determining region (RRDR) mutations from 507 until 533 codons and kat $G$ and/or inhA gene mutations that are associated with Rifampicin and Isoniazid resistance. ${ }^{13}$

Therefore, Pyrosequencing can diagnose MDR-TB more accurately. ${ }^{10,11,13}$ This study aimed to determine whether these two methods have the same interpretation and to determine the differences in codon mutation position detection of the $r p o B$ gene as well as mutation detection of the katG and/or inhA gene based on the Pyrosequencing results.

\section{Methods}

A comparative observational study with a crosssectional design was used in this study. Subjects were patients $\geq 18$ years old interpreted as RR-TB based on the Xpert MTB/RIF assay results from Dr. Hasan Sadikin General Hospital Bandung, Indonesia, who had not received MDR-TB drugs yet. This study used 40 biological materials from sputum stored in the form of DNA isolates in $-80^{\circ} \mathrm{C}$ freezer under daily temperature monitoring from a study on the association between minimum inhibitory concentration and gene mutation related to drug resistance in patients with multi/extensively drug-resistant tuberculosis in Indonesia in 2015. There was no electricity problem during the storage period. The exclusion criteria was the volume of biological materials $<20 \mu \mathrm{L}$. Sputum used for the Pyrosequencing differed from the Xpert MTB/ RIF assay.

This study was conducted at the TB Biomolecular Laboratorium of the West Java Provincial Health Laboratory, Indonesia during the period of January-February 2020. The real-time PCR Quality Control (QC) used DNA template and primer to amplify the IS6110 gene as MTB positive control. Pyrosequencing detected the IS6110 gene and genetic mutations within rpoB, inhA, katG, eis, gyrA, and rrs gene. Pyrogram and its interpretation were released after the Pyrosequencing process. ${ }^{13}$ This study was approved by the Health Research Ethics Committee of Universitas Padjadjaran Bandung through the issuance of ethical approval no. 77/UN6.KEP/EC/2020. Data analysis were performed using the Statistical Package for the Social Sciences (SPSS) software version 24.0 for Windows.

\section{Results}

In total, 40 RR-TB subjects based on the interpretation using the Xpert MTB/RIF assay were recruited. When the samples underwent Pyrosequencing, 30 MDR-TB subjects, 9 RR-TB subjects, and one Isoniazid-resistant TB subject were identified as listed in Table 1.

The proportion of codon mutation position detection of the $r p o B$ gene between the Xpert MTB/RIF assay and the Pyrosequencing methods are presented in Table 2. Mutation in 529-533 codons was the most prevalent, and 
Table 1 Rifampicin-Resistant Tuberculosis Interpretation Based on the Xpert MTB/RIF Assay and Pyrosequencing $(n=40)$

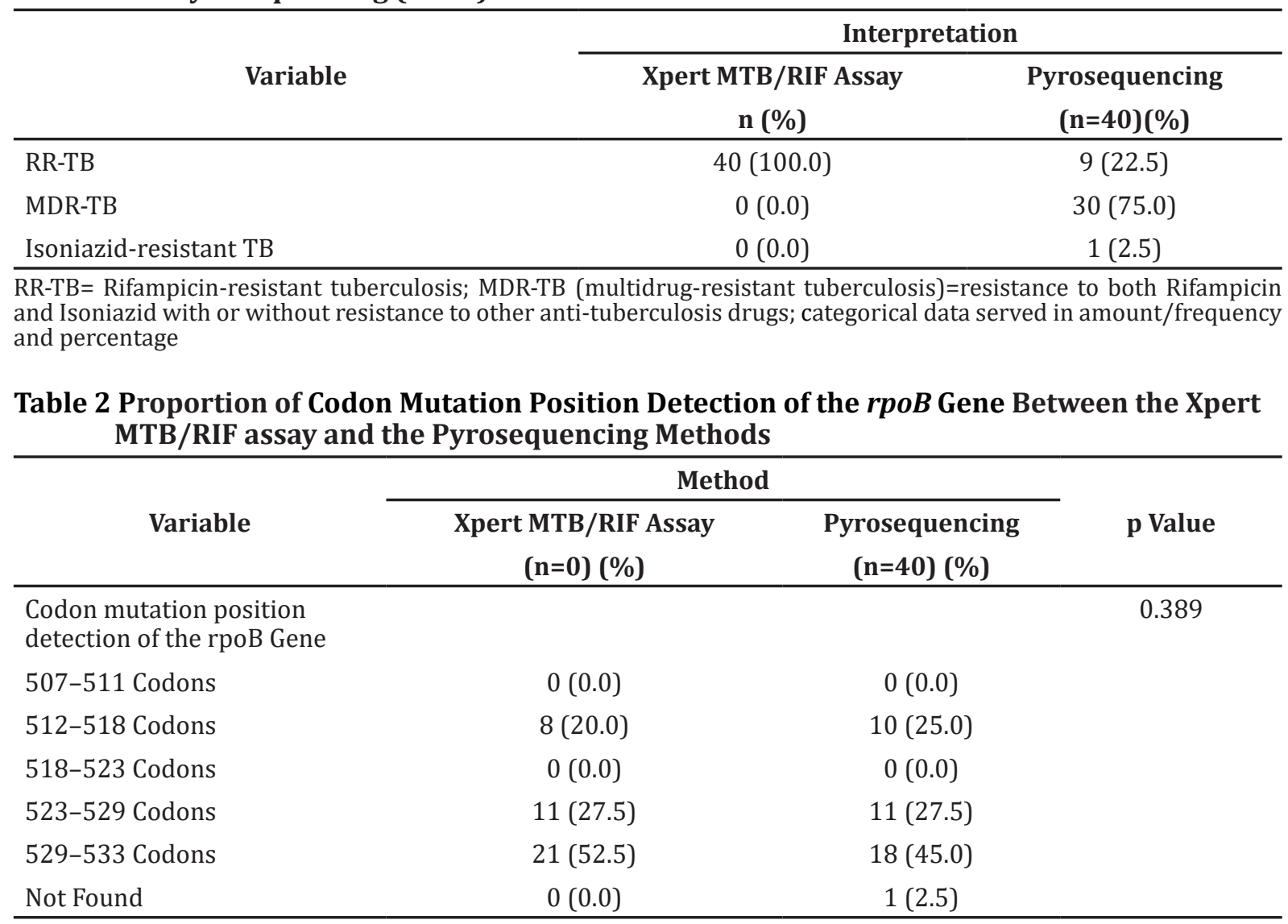

$\mathrm{p}$-value counted by Wilcoxon test for ordinal data; $\mathrm{p}<0.05$ has a significant difference

was found in $21(52.5 \%)$ subjects by the Xpert MTB/RIF assay and $18(45.0 \%)$ subjects by the Pyrosequencing. Although the proportion of codon mutation position detection of the rpoB gene between the Xpert MTB/RIF assay and the Pyrosequencing method was not the same, they were not significantly different $(\mathrm{p}=0.389)$. Two subjects had additional codon mutation positions detected in 512-518 codons by the

Table 3 katG and inhA Gene Mutation Detection by Pyrosequencing

\begin{tabular}{lc}
\hline \multicolumn{1}{c}{ Variable } & $(\mathbf{n = 4 0 )}(\%)$ \\
\hline Gene mutation detection & $27(67.5)$ \\
katG gene & $3(7.5)$ \\
inhA gene & $1(2.5)$ \\
katG \& inhA gene & $9(22.5)$ \\
No katG \& inhA gene mutation &
\end{tabular}

categorical data served in amount/frequency and percentage
Pyrosequencing. Pyrosequencing detected 27 kat $G$ gene mutations, 3 inhA gene mutations, one katG, and inhA gene mutation, and 9 with no kat $G$ and $i n h A$ gene mutations as demonstrated in Table 3.

katG gene mutation detection based on the Pyrosequencing was found more than inhA gene mutation detection, with 27 subjects or $67.5 \%$ from 40 RR-TB subjects based on the Xpert MTB/ RIF assay.

\section{Discussion}

To the best of our knowledge, this was the first study to compare the interpretation between the Xpert MTB/RIF assay and the Pyrosequencing in MDR-TB in Indonesia. There were 40 RRTB subjects from the Xpert MTB/RIF assay interpretation diagnosed as MDR-TB, based on the Pyrosequencing method. There were 30 MDR-TB subjects, 9 RR-TB subjects, and one Isoniazid-resistant TB participated in this 
study. 2,10,11,13 Pyrosequencing interpreted one Isoniazid-resistant $\mathrm{TB}$ subject from 40 RR-TB subjects based on the Xpert MTB/RIF assay. It was assumed that the mutation in the $r p o B$ gene detected by the Xpert MTB/RIF assay might not be covered by Pyrosequencing.

A thorough internal QC was performed for the Xpert MTB/RIF assay. All samples passed the Sample Processing Control (SPC) and Probe Check Control (PCC). ${ }^{5,14}$ Mycobacterium tuberculosis was detected in all samples through minimal 4 from 5 probes produced fluorescence at $\mathrm{C}_{\mathrm{T}} \leq 39$ cycles for $\mathrm{A}, \mathrm{B}$, and $\mathrm{C}$ probes and also $\mathrm{C}_{\mathrm{T}}$ $\leq 36$ cycles for $\mathrm{D}$ and $\mathrm{E}$ probes with $\Delta \mathrm{C}_{\mathrm{T}}$ minimum $<2$ cycles. ${ }^{14}$ Real-time PCR QC had been done to all samples using primers that amplified $I S 6110$ gene as MTB positive control, rpoB1, rpoB2, inhA, katG, eis, gyrA, and rrs gene until $\mathrm{C}_{\mathrm{T}}$ value was seen. Pyrosequencing had detected the IS6110 gene, rpoB1, rpoB2, inhA, katG, eis, gyrA, and rrs gene in all samples. All samples also passed the control negative test passed. ${ }^{13}$ This discrepancy could relate to the MTB dual-population or heteroresistance. ${ }^{15}$ Heteroresistance might be particularly common in regions with a high rate of TB, especially drug-resistant TB. About 1,37$28,8 \%$ of patients infected by MTB might have Rifampicin heteroresistance in their body. ${ }^{16}$ Rifampicin-sensitive and Rifampicin-resistant MTB could be detected by phenotypic and/or genotypic drug susceptibility testing (DST) of MTB from the same sample that contained $\geq 1 \%$ Rifampicin-resistant MTB. ${ }^{16,17}$

Although the proportion of codon mutation position detection of the $r p o B$ gene between the Xpert MTB/RIF assay and the Pyrosequencing methods was not the same, they were not significantly different $(p=0.389)$ either. This discrepancy could relate to MTB heteroresistance. There was a change in the base sequence of DNA that differed from the rpoB gene wild-type. There were two Rifampicin-resistant MTB populations from one MTB culture isolate with a different base sequence of the rроB gene based on the Pyrosequencing. ${ }^{18}$ Discrepancy could relate with different samples used. ${ }^{16}$ This study used two samples from one subject who had not received MDR-TB drugs yet for the Xpert MTB/RIF assay and the Pyrosequencing tests.

Heteroresistance happened in two subjects who had rpoB gene mutations in one codon based on the Xpert MTB/RIF assay while the Pyrosequencing had detected $r р о B$ gene mutations in two codons. There were $r p o B$ gene mutations in 516 and 531 codons based on the Pyrosequencing, while the Xpert MTB/RIF assay had detected $r p o B$ gene mutation in 529533 codons (Probe E). There were rро $B$ gene mutations in 516 and 526 codons based on the Pyrosequencing, while the Xpert MTB/RIF assay had detected rpoB gene mutation in 523-529 codons (Probe D). A patient might be infected with $\geq 1$ MTB strain with different patterns of drug resistance. ${ }^{19}$

Pyrosequencing had detected $27 \mathrm{katG}$ gene mutations or $67.5 \%, 3$ inhA gene mutations or $7.5 \%$, one $k a t G$ and inhA gene mutation or $2.5 \%$, and 9 with no katG and inhA gene mutations or $22.5 \%$ from 40 RR-TB subjects based on the Xpert MTB/RIF assay. There were 50-95\% Isoniazid-resistant TB caused by katG gene mutations while $20-35 \%$ was caused by inhA gene mutations ${ }^{8,20}$ katG gene mutations detected by the Pyrosequencing were found more than inhA gene mutations in this study. Nine subjects had no katG and inhA gene mutations with rpoB gene mutations interpreted as RR-TB based on the Pyrosequencing. This study has encountered limitation because confirmation test with Whole Genome Sequencing (WGS) for the subjects that have discrepancy interpretation between the Xpert MTB/RIF assay and the Pyrosequencing has not been done yet, due to a high cost.

To conclude, the interpretation between the Xpert MTB/RIF assay and the Pyrosequencing in MDR-TB is different. There are 40 RRTB subjects from the Xpert MTB/RIF assay interpretation diagnosed as MDR-TB, based on the Pyrosequencing method. There are 30 MDRTB subjects, 9 RR-TB subjects, and one Isoniazidresistant TB. The detection of rpoB gene codon mutation position between the Xpert MTB/ RIF assay and the Pyrosequencing methods is not significantly different $(\mathrm{p}=0.389)$. The Xpert MTB/RIF assay diagnoses MDR-TB based on Rifampicin resistance even though the definition of MDR-TB is resistance to at least two of the most potent tuberculosis drugs, Rifampicin and Isoniazid while the Pyrosequencing can detect MDR-TB based on resistance to Rifampicin and Isoniazid. The advantages of Xpert MTB/RIF assay are rapid and easy to perform. Therefore, the Xpert MTB/RIF assay can be used for MDRTB screening, while the Pyrosequencing can detect MDR-TB more accurately although it needs a longer time.

\section{Acknowledgment}

Part of this study was funded by Sistem Informasi Penelitian dan Pengabdian Kepada Masyarakat 
(SIMLITABMAS) under "Using Host-Responses and Pathogen Genomics to Improve Diagnostics for Tuberculosis in Indonesia" study.

\section{References}

1. WHO. Global tuberculosis report 2019. France: WHO; 2019.

2. Hamze M, Ismail MB, Rahmo AK, Dabboussi F. Pyrosequencing for rapid detection of tuberculosis resistance to Rifampicin and Isoniazid in Syrian and Lebanese clinical isolates. Int J Mycobacteriol. 2015;4(3):22832.

3. Lawn SD, Nicol MP. Xpert MTB/RIF assay: development, evaluation and implementation of a new rapid molecular diagnostic for tuberculosis and Rifampicin resistance. Future Microbiology. 2011;6(9): 1067-82.

4. Albert $\mathrm{H}$, Nathavitharana RR, Isaacs $\mathrm{C}$, Pai M, Denkinger CM, Boehme CC. Development, roll-out and impact of Xpert MTB/RIF for tuberculosis: what lessons have we learnt and how can we do better?. Eur Respir J. 2016;48(2):516-25.

5. Bodmer T, Ströhle A. Diagnosing pulmonary tuberculosis with the Xpert MTB/RIF test. J Vis Exp. 2012;(62):e3547.

6. Ocheretina O, Byrt E, Mabou M, Royal-Mardi G, Merveille Y, Rouzier V, et al. False-positive Rifampin resistant results with Xpert MTB/ RIF version 4 assay in clinical samples with a low bacterial load. Diagn Microbiol Infect Dis. 2016;85(1):53-5.

7. Kaur R, Jindal N, Arora S, Kataria S. Epidemiology of Rifampicin resistant tuberculosis and common mutations in rpoB gene of Mycobacterium tuberculosis: a retrospective study from six districts of Punjab (India) using Xpert MTB/RIF assay. J Lab Physicians. 2016;8(2):96-100.

8. Garza-Gonzalez E, Gonzalez GM, Renteria A, Cruz-Pulido WL, Rivera G, Bocanegra-Garcia V. A Pyrosequencing method for molecular monitoring of regions in the inhA, ahpC and rpoB genes of Mycobacterium tuberculosis. Clin Microbiol Infect. 2010;16(6):607-12.

9. Seifert M, Catanzaro D, Catanzaro A, Rodwell TC. Genetic mutations associated with Isoniazid resistance in Mycobacterium tuberculosis: a systematic review. PLoS ONE. 2015;10(3):1-13.

10. Harrington CT, Lin EI, Olson MT, Eshleman JR. Fundamentals of pyrosequencing. Arch Pathol Lab Med. 2013;137(9):1296-303.

11. Zheng R, Zhu C, Guo Q, Qin L, Wang J, Lu J, et al. Pyrosequencing for rapid detection of tuberculosis resistance in clinical isolates and sputum samples from re-treatment pulmonary tuberculosis patients. BMC Infect Dis. 2014;14:200.

12. USAID. International Standards for Tuberculosis Care. TB care I. 3rd ed. San Fransisco: United States Agency for International Development (USAID); 2014.

13. Pyrobett. MXDR-TB test user manual. Singapore: Pyrobett Joint Lab Genome Institute; 2017.

14. GeneXpert. Xpert MTB/RIF assay. Revision F ed. USA: Cepheid Innovation; 2019.

15. Ajbani K, Tornheim J, Naik S, Soman R, Shetty A, Rodrigues C. Pyrosequencing to resolve discrepant Xpert MTB/RIF and mycobacterial growth indicator tube 960 . Lung India. 2018;35(2):168-70.

16. Zheng $\mathrm{C}$, Li S, Luo Z, Pi R, Sun $\mathrm{H}, \mathrm{He}$ $\mathrm{Q}$ et al. Mixed infection and Rifampin heteroresistance among Mycobacterium tuberculosis clinical isolates. J Clin Microbiol. 2015;53(7):2138-47.

17. Folkvardsen DB, Thomsen VO, Rogouts L, Rasmussen EM, Bang D, Bernaerts $\mathrm{G}$, et al. Rifampin heteroresistance in Mycobacterium tuberculosis cultures as detected by phenotypic and genotypic drug susceptibility test methods. J Clin Microbiol. 2013;51(12):4220-2.

18. Engstrom A, Hoffner S, Jureen P. Detection of heteroresistant Mycobacterium tuberculosis by Pyrosequencing. J Clin Microbiol. 2013;51(12):4210-2.

19. Baffoe-Bonnie A, Houpt ER, Turner L, Dodge D, Heysell SK. Drug-susceptible and multidrug-resistant Mycobacterium tuberculosis in a single patient. Emerging Infectious Diseases. 2019;25(11):2120-1.

20. Aung WW, Ei PW, Nyunt WW, Swe TL, Lwin T, Htwe MM, et al. Phenotypic and genotypic analysis of anti-tuberculosis drug resistance in Mycobacterium tuberculosis isolates in Myanmar. Ann Lab Medicin. 2015; 35(5):494-9. 